\title{
PERANAN PROGRAM KOPERASI JASA KEUANGAN SYARIAH BAITUL MAAL WAT TAMWIL ( KJKS BMT) DALAM PEMBERDAYAAN PELAKU USAHA MIKRO KECIL MENENGAH DI KOTA PADANG
}

\author{
Rizki Afri Mulia ${ }^{1}$ \\ Ilmu Administrasi Negara, STISIP Imam Bonjol Padang
}

\begin{abstract}
This research background was found in the implementation of the program Baitul Maal Wat Tamwil (BMT) in Empowerment's actors UMKM in Padang. The aims of this research was to describe the implementation of Sharia Baitul Maal Wat Tamwil (KJKS BMT) Cooperative Program and to know the impact of KJKS Program implementation through savings and loan program in approaching the access of business capital to SMEs in Padang City. The method used in this research was qualitative research using descriptive method. The research found that the Role of Sharia Financial Services Cooperative Program Baitul Maal Wat Tamwil (KJKS BMT) for the Empowerment of Micro Small Medium Enterprises has been effective by providing financing in the addition of venture capital to UMKM for the development of their business. Although the implementation of KJKS program has been in accordance with existing procedures but has not fully able to improve the welfare of its members. This can be seen from its still found some obstacles in the implementation, constraints faced can be categorized into two forms. Internal obstacles such as: lack of KJKS capital, poor people's mindset about KJKS program, lack of supervision on KJKS program implementation, external constraints such as: the utilization of aid funds that have not maximized, Fructuative Community Economic Condition (unstable), Competitor with product Just like the existence of loan sharks, obstacles that come from the participants of the program carried out efforts such as guidance, the system pick up the ball against members who are stuck in the payment.
\end{abstract}

Keywords: Role, Community Empowerment, UMKM, KJKS Program

\section{PENDAHULUAN}

Proses pemberdayaan menekankan pada proses memberikan kemampuan kepada masyarakat akan menjadi berdaya, mendorong atau memotivasi individu agar mempunyai kemampuan atau keberdayaan untuk menentukan pilihan hidupnya. Orientasi usaha pemberdayaa ini bisa tertuju pada sektor usahanya, dengan memberikan motivasi atau dukungan dan peluang usaha serta tertuju kepada individu sendiri dengan memberikan pendidikan dan keterampilan atau pelatihan untuk memulai suatu usaha. BMT merupakan

\footnotetext{
1 'Dosen STISIP Imam Bonjol Padang'.
} 
bagian dari lembaga keuangan mikro telah lama menjadi sarana yang efektif untuk mengembangkan perekonomian rakyat dan memberdayakan rakyat miskin. Pada saat intermediasi perbankan belum berfungsi secara optimal, maka keberadaan LKM atau BMT semakin penting dalam menegakkan sektor riil. ${ }^{2}$

Tugas utama pemerintah sebagai organisasi sektor Publik terbesar adalah untuk menciptakan kesejahteraan masyarakat. Dalam suatu pemerintahan yang demokrasi, hubungan antara pemerintah dan masyarakat dapat digambarkan sebagai hubungan keagenan dalam hal ini pemerintah berfungsi sebagai agen yang diberi kewenangan untuk melaksanakan kewajiban tertentu oleh masyarakat sebagai prinsipal. ${ }^{3}$

Menurut Undang-Undang Republik Indonesia Nomor 25 Tahun 1992 bahwa Koperasi baik sebagai gerakan ekonomi rakyat maupun sebagai badan usaha berperanan serta untuk mewujudkan masyarakat yang maju, adil dan makmur berdasarkan pancasila dan Undang-undang Dasar 1945 dalam tata perekonomian nasional yang disusun sebagai usaha bersama berdasarkan atas asas kekeluargaan dan demokrasi ekonomi.

Kemiskinan merupakan fenomena kehidupan nyata, yang menyertai kehidupan manusia dari masa ke masa. Berbagai upaya telah dilakukan untuk menanggulanginya. Saat ini, berkembang paradigma baru dalam upaya pengentasan kemiskinan tersebut. Dalam Mikro credit Summit 2002 misalnya, telah menyepakati paradigma baru dalam pengentasan kemiskinan melalui pendekatan keuangan mikro atau micro-finance. Hal ini merupakan penyempurnaan dari pendekatan pada tahap sebelumnya yang lebih menekankan pada program-program langsung yang bersifat subsidi. Upaya memberdayakan sekaligus mengentaskan kemiskinan adalah dengan menciptakan suatu tatanan dimana masyarakat miskin dapat melakukan akses kelembaga permodalan dengan relatif mudah. Akses ini khususnya digunakan untuk modal usaha yang diharapkan sedikit demi sedikit mampu mengentaskan kemiskinan yang dialami masyarakat (Pusat Inkubasi Bisnis Usaha Keci) (PINBUK).

Sebelum adanya lembaga simpan pinjam syariah, masyarakat kecil dan menengah dalam menambah modal usahanya dengan cara meminjam kepada rentenir atau lembaga

\footnotetext{
2 Jaka Sriyana and Fitri Raya, 'Peran Bmt Dalam Mengatasi Kemiskinan Di Kabupaten Bantul', Inferensi, 7.1 (2013), 29 <https://doi.org/10.18326/infsl3.v7i1.29-50>.

${ }^{3}$ M Mahmudi, 'Manajemen Kinerja Sektor Publik’ (Yogyakarta: UPP-STIM YKPN, 2010).
} 
simpan pinjam konvensional yang beban bunganya cukup tinggi serta cara mengakses sumber pendanaan dari bank yang terlalu sulit bagi masyarakat menengah kebawah. Hal ini disebabkan terbentur pada sistem dan prosedur pembiayaan yang berlaku terkesan rumit, sehingga masyarakat tidak mampu memenuhi prosedur perbankan tersebut. Mengetahui fenomena tersebut Pusat Inkubasi Bisnis Usaha Kecil (PINBUK) merasa prihatin terhadap usaha kecil dan menengah, sehingga mulai merumuskan sistem keuangan yang lebih sesuai dengan kondisi usaha kecil dan sesuai dengan prinsip syariah Islam. Alternatif tersebut adalah dengan terealisasinya Baitul Maal Wat Tamwil (BMT) di kalangan masyarakat. ${ }^{4}$

Berpijak dari kenyataan tersebut di atas, Pemerintah Kota Padang bermaksud mendirikan Lembaga Keuangan Mikro Baitul Maal Wat Tamwil untuk memberikan akses bagi UMKM dalam memperoleh sumber-sumber permodalan dan pendampingan dari KJKS-BMT dalam bidang manajemen usaha, sosial maupun moral, akhlak, dan etika bisnis pelaku usaha hal ini diperkuat dengan Peraturan Walikota Nomor 4.A tahun 2013 tentang Program Penanggulangan kemiskinan melalui pengembangan Koperasi jasa Keuangan Syariah Baitul Maal Wat Tamwil Kelurahan.

Program KJKS dirintis pada tahun 2010 dan tersebar di 104 kelurahan di Kota Padang. Pendirian KJKS ini dilakukan bertahap, yaitu pada tahun 2010 didirikan 54 KJKS, dan dilanjutkan pada tahun 2011 dengan mendirikan 20 KJKS. Pada tahun 2012 dikembangkan lagi pada 30 Kelurahan, dan tahun 2013 berdiri lagi 20 KJKS. Sehingga total keseluruhan ada 104 KJKS yang tersebar pada 11 Kecamatan di Kota Padang.

Keberadaan UMKM dalam perekonomian Indonesia menempati posisi yang kurang menguntungkan dalam sektor perekonomian berkenaan dengan masalah pendanaan dari UMKM tersebut. Tidak cukupnya dana yang tersedia membuat UMKM kesulitan untuk mengembangkan usahanya, apalagi di era globalisasi seperti sekarang ini. Berdasarkan survey Biro Pusat Statistik (BPS) ada tiga jenis kesulitan yang harus dihadapi Usaha Kecil dan Menengah dalam menjalankan usahanya, yaitu a) ketersediaan bahan baku b) masalah permodalan c) masalah pemasaran.

\footnotetext{
${ }^{4}$ Heri Sudarsono, Bank dan Lembaga Keuangan Syariah (Ekonisia, 2008).
} 


\section{METODE PENELITIAN}

Penelitian ini menggunakan pendekatan metode kualitatif. Penelitian kualitatif bertujuan untuk menjelaskan fenomena yang sedalam-dalamnya tanpa mengutamakan besarnya populasi dan sampling. Penelitian kualitatif ini bersifat deskripstif. Penelitian dilakukan di sekitar lingkungan Kota Padang. Dalam penelitian ini pengambilan informan penelitian dilakukan dengan menggunakan teknik purposive sampling yaitu menentukan informan dengan pertimbangan tertentu yang dipandang dapat memberikan data secara maksimal, artinya orang yang betul-betul memahami permasalahan yang diteliti. Instrumen penelitian adalah peneliti sendiri yang bertindak sebagai perencana, pelaksana dalam pengumpulan data, melakukan analisis, menafsirkan data, dan melakukan laporan penelitian.

\section{PEMBAHASAN}

\section{Upaya peran program KJKS BMT dalam Pemberdayaan UMKM di Kota Padang}

Agar dapat mencapai upaya pemberdayaan harus dilakukan melalui tiga arah. ${ }^{5}$

a. Menciptakan suasana iklim yang memungkinkan potensi masyarakat berkembang (enabling), Artinya, setiap manusia atau setiap masyarakat telah memilki potensi, sehingga pada saat melaksanakan langkah pemberdayaan diupayakan agar mendorong dan membangkitakn kesadaran masyarakat akan pentingnya mengembangkan potensi-potensi yang telah dimiliki.

b. Memperkuat potensi atau daya yang dimiliki masyarakat (empowering). Langkah pemberdayaan diupayakan melalui aksi-aksi nyata seperti pendidikan, pelatihan, peningakatan kesehatan, pemberian modal, informasi, lapangan kerja, pasar serta sarana dan prasarana lainnya.

c. Melindungi masayrakat (protection). Artinya, dalam pemberdayaan masyarakat perlu di upayakan langkah-langkah yang perlu mencegah persaingan secara tidak seimbang serta praktik eksploitasi yang kuat terhadap yang lemah, melalui keberpihakan atau adanya aturan atau kesepakatan yang jelas dan tegas untuk melindungi golongan yang lemah.

Program KJKS BMT merupakan salah upaya yang dilakukan oleh pemerintah Kota Padang dalam rangka menekan angka kemiskinan, melalui lembaga simpan pinjam, diharapkan masyarakat miskin bisa terbantu serta memiliki akses untuk penambahan modal usaha memperlancar kegiatan pelaku usaha dalam mengembangkan usaha mereka hal ini akan berdampak terhadap meningkatkan kesejahteraan selain itu juga untuk memperlancar mobilitas penduduk hal ini sesuai dengan tiga arah pemberdayaan menurut Kartasasmita dalam Zubaedi dimana Pemerintah Kota Padang ingin memberdayakan pelaku UMKM yang mengalami kendala dengan modal usaha mereka dengan memberikan pinjaman lunak melalui lembaga simpanan pinjam KJKS BMT, hal ini diharapkan agar pelaku atau masyarakat yang menjadi anggota KJKS terdorong serta membangkitkan kesadaran

${ }^{5}$ Zubaedi, Pengembangan M asyarakat Wancana Dan Praktik, Ed 1. (Jakarta: Kencana, 2013). 
masyarakat akan pentingnya mengembangkan potensi-potensi yang telah dimiliki sehingga produk-produk yang dimiliki oleh UMKM dapat bersaing dengan perusahaan-perusahan yang memiliki modal besar.

Dari hasil temuan penelitian upaya Program KJKS BMT untuk pemberdayaan pelaku UMKM di Kota Padang harus terlaksana dengan maksimal menyentuh seluruh lapisan masyarakat dengan merancang dan mengelola seluruh potensi yang ada ditengah-tengah masyarakat. KJKS BMT merupakan upaya Pemerintah dalam mengentaskan kemiskinan dan pengangguran di Kota Padang untuk itu kelembagaan KJKS BMT harus dikelola dengan profesional serta dituntut kreatif dalam menciptakan berbagai program dan usaha-usaha koperasi. Sejak dibentuk pada tahun 2010 sampai 2014 telah telah terdapat 104 KJKS yang menyebar di setiap Kelurahan di Kota Padang yang bertujuan menurunkan garis kemiskinan penduduk Kota padang namun tingkat penurunan disetiap tahunnya tidak terlalu memberikan dampak yang signifikan terhadap penurunan Penduduk miskin di Kota Padang hal ini menggambarkan bahwa program KJKS BMT kurang efektif menurunkan kemiskinan.

Strategi koperasi jasa keuangan syariah Arrahmah dalam menekan Tingkat Non Performing Financing (NPF) yaitu selalu mematuhi SOP pengajuan pembiayaan yang telah ditetapkan perusahaan, memberikan hadiah bagi anggota yang pembiayaannya lancar, sering melakukan kunjungan ke anggota, melakukan binaan terhadap usaha anggota, dan sering bersilaturrahmi dengan anggota. Strategi yang diterapkan Koperasi Jasa Keuangan Syariah Arrahmah sudah cukup efektif berdasarkan laporan keuangan KJKS Arrahmah yaitu dari tahun 2006 tingkat NPF nya sebesar 3,3\%, pada tahun 2007 sebesar 3\%, dan pada tahun 2008 sebesar 2,3\%.walaupun tidak terlalu signifikan tetapi mengalami penurunan setiap tahunnya antara $0,3 \%$ hingga $0,7 \%{ }^{6}$

\section{Peran program Koperasi Jasa Keuangan Syariah Baitul Maal Wat Tamwil ( KJKS BMT) Dalam Membina UMKM Di Kota Padang}

Menurut Undang-Undang Republik Indonesia Nomor 25 Tahun 1992 bahwa Koperasi baik sebagai gerakan ekonomi rakyat maupun sebagai badan usaha berperanan serta untuk mewujudkan masyarakat yang maju, adil dan makmur berdasarkan pancasila dan Undang-undang Dasar 1945 dalam tata perekonomian nasional yang disusun sebagai usaha bersama berdasarkan atas asas kekeluargaan dan demokrasi ekonomi.

a. Implementasi Program

Salah satu faktor pendukung tercapainya tujuan suatu program KJKS adalah pelaksanaannya. Apabila pelaksanaan suatu program baik dan tepat sasaran, maka program tersebut dapat memberikan dampak yang baik juga terhadap masyarakat. KJKS Mandiri Sejahtera menjadi salah satu alternatif bagi masyarakat dalam meningkatkan pemberdayaan ekonomi, khususnya dikalangan usaha mikro dan kecil menengah, mendorong kehidupan ekonomi syariah, serta meningkatkan semangat dan peran serta anggota masyarakat dalam kegiatan Koperasi Jasa Keuangan Syariah.

\footnotetext{
${ }^{6}$ Aan Afrianti, 'Stratetegi Koperasi Jasa Keuangan Syariah Dalam Menekan Tingkat Non Performing Financing ( NPF): Studi Kasus Pada KJK Syariah Arrahmah Cinere' (UIN Syarif Hidayatullah, 2010).
} 
Berdasarkan keputusan bersama tiga menteri dan Gubernur 2009 tentang Strategi pengembangan lembaga keuangan mikro berbadan hukum, menyatakan bahwa lembaga keuangan mikro yang belum berbadan hukum segera di bentuk atas inisiatif pemerintah, pemerintah daerah dan atau masyarakat yang mengelola dana-dana masyarakat harus ditransformasi menjadi lembaga keuangan mikro berbadan hukum dalam bentuk Bank Pengkreditan Rakyat (BPR), BUMD/BUMK atau Koperasi. Menindak lanjuti keputusan tiga menteri, Pemko Padang mengeluarkan Perwako No. 15 Tahun 2010. Tentang program penanggulangan kemiskinan melalui pengembangan koperasi jasa keuangan Syariah Baitul, Maal Wat Tamwil (KJKS BMT) Padang Amanah Sejahtera.

Perwako No. 15 di revisi menjadi Perwako No. 13 Tahun 2014 tentang penanggulangan kemiskinan melalui pengembangan KJKS BMT Kelurahan, dengan di kebunnya KMK Kelurahan menjadi KJKS BMT Kelurahan akan mempetkuat keberadaan KJKS BMT dalam membantu modal usaha bagi masyarakat miskin, serta dana Rp. 300 Juta tersebut juga bisa jadi modal awal pendirian KJKS BMT.

Wakil Walikota mengingatkan sejak program transformasi KMK ke KJKS, timbul beberapa permasalahan di masyarakat terkait dengan belum seluruhnya dana KMK di 50 Kelurahan Ditransformasikan ke KJKS, di akibatkan gempa 2009 lalu, di mana perekonomian masyarakat miskin semakin terpuruk tak mampu mengansur hutang.

Tujuan pelaksanaan Program Koperasi Jasa Keuangan Syariah Baitul Maal Wat Tamwil (KJKS BMT) adalah: untuk mendukung program Kredit Mikro dan recovery ekonomi pasca gempa di kota Padang bagi penanggulangan kemiskinan dan penciptaan kesempatan dan lapangan kerja bagi masyarakat banyak. Dalam RPJP tahun 2014-2019 tertuang beberapa Program Unggulan Walikota Padang diantaranya:

1) Program penciptaan iklim usaha yang kondusif

2) Program pengembangan kewirausahaan dan keunggulan kompetitif bagi UMKM

3) Program peningkatan produktivitas dan sistem pendukung usaha bagi Koperasi dan UMKM

4) Program peningkatan kualitas kelembagaan koperasi

5) Program Peningkatan dan Pengembangan Usaha Koperasi

6) Program peningkatan kualitas kelembagaan lembaga keuangan mikro.

Dilihat dari program-program yang diungulkan Walikota Padang ini Pemerintah Kota Padang benar-benar memberikan dukungan penuh dalam peningkatan lembaga KJKS sebagai salah satu program untuk menekan angka kemiskinan di Kota Padang dengan memberdayakan pelaku UMKM dengan lebih mendekatkan lagi akses penambahan modal lewat lembaga simpan pinjam yang ada di 104 Kelurahan yang menyebar di Kota Padang.

Perkembangan warga miskin yang menerima bantuan modal usaha melalui pembiayaan di KJKS masih kurang maksimal hal ini bisa dilihat dari cakupan 
penerima dana KJKS belum memenuhi target realisasi dari program yaitu minimal $70 \%$ dari keluarga miskin yang terdaftar dalam database penduduk miskin Kota Padang tahun 2016 yaitu 37.072 KK RTM dan hanya terealisasi sekitar 14.410 KK RTM.

KJKS merupakan organisasi terstruktur tokoh masyarakat, setiap unsur yang berpotensi mempengaruhi masyarakat di Kelurahan mempunyai tugas meningkatkan ekonomi diwilayah mereka dengan bantuan penambahan modal usaha lewat pembiayaan yang dilakukan di KJKS semua unsur tesebut harus bekerja keras, jujur, iklas serta bersinergi dalam meningkatkan KJKS BMT yang memakai sistim syariah, ini merupakan kunci keberhasilan KJKS BMT untuk dapat lebih berkembang, namun selama ini masih ada terjadi perselisihan mengakibatkan koordinasi yang terbangun kurang bagus dan menghambat laju pertumbuhan dari KJKS bisa dilihat dari Cakupan warga miskin penerima dana KJKS masih sangat sedikit mengisyaratkan bahwa kinerja yang kurang efektif dari setiap unsur dalam berada di KJKS karena perselisihan yang terjadi maka sinergi antara unsur-unsur yang ada di Kelurahan menjadi tidak kondusif hal ini dapat menghambat perkembangan KJKS. Program KJKS juga dapat memperlancar kegiatan perekonomian, meningkatkan kesejahteraan selain itu juga untuk memperlancar mobilitas penduduk namun hal ini tidak terlepas dari pengawasan dan bimbingan dari berbagai pihak yakni pemerintah setempat mulai dari Camat, lurah dan pemuka masyarakat, Pengelola, satuan kerja, fasilitator serta masyarakat.

Setiap UMKM pasti memiliki daya, akan tetapi kadang-kadang pihak UMKM sendiri tidak menyadari, atau sumber daya yang dimiliki tersebut masih belum dapat diketahui secara eksplisit. Oleh karena itu sumber daya yang ada harus digali, dan kemudian dikembangkan, jika asumsi ini yang berkembang maka pemberdaya pelaku UMKM dapat dikatakan sebagai upaya untuk membangun daya yang dimiliki UMKM, dengan cara mendorong, memotivasi dan membangkitkan kesadaran akan potensi yang dimiliki serta beruaya untuk mengembangkannya.

b. Konteks program

Program KJKS BMT dilaksanakan untuk pemberdayakan ekonomi masyarakat dengan memberikan bantuan berupa dana bergulir guna penambahan modal usaha bagi UMKM yang mudah di akses oleh masyarakat Kelurahan dalam upaya meningkatkan perekonomian dan kesejahteraan. KJKS BMT dapat mengurangi kegiatan yang besifat ribawi dan rentenir ditengah-tengah masyarakat miskin yang terdapat di Kota Padang.

Pelaksanaan Peran Program KJKS BMT di Kota Padang dari hasil penelitian dapat terlihat bahwa perencanaan program KJKS BMT adalah salah satu upaya Pemerintah dalam mengentaskan kemiskinan dan pengangguran di Kota Padang. Terlaksananya Program KJKS BMT ini tentunya memerlukan keseriusan dan dukungan dari berbagai pihak baik dari pemerintah maupun masyarakat dalam semua tahapan proses penyelengaraan kegiatannya.

Konteks Program KJKS merupakan program percepatan penurunan kemiskinan, dari tahun 2010 sampai 2014 telah dibentuk 104 KJKS BMT di kota Padang terlaksananya program dengan baik perlu adanya pembagian tugas serta 
sosialisasi yang baik juga. Salah satu faktor pendukung tujuan program KJKS adalah pelaksanaan program KJKS dengan baik, masih adanya masyarakat yang menganggap program ini adalah uang pemerintah maka tidak masalah kalau pembiayaan yang diberikan tidak dikembalikan lagi, hal ini akan menghambat perkembangan usaha dari Program KJKS untuk itu di perlukan sosialisasi yang lebih baik lagi tentang program ini. KJKS dipercaya untuk menjalankan program pengetasan kemiskinan dan pemberdayaan perekonomian masyarakat bersama pemerintah. KJKS merupakan salah satu langkah strategis yang ditempuh pemerintah Kota Padang dalam upaya penanggulangan kemiskinan, dengan bekerjasama langsung dengan masyarakat. KJKS diharapkan sebagai wadah pengembangan perekonomian masyarakat Kelurahan yang miskin. ${ }^{7}$

Ada perbedaan dalam hal modal usaha, omzet penjualan dan keuntungan UMK sebelum dan sesudah memperoleh pembiayaan dari BMT At Taqwa Halmahera Kota Semarang khususnya yang menjadi anggotanya. Dari variabel modal usaha, omzet penjualan dan keuntungan dalam UMK sesudah memperoleh pembiayaan dari BMT At Taqwa Halmahera terbukti mempunyai pengaruh positif terhadap kinerja UMK binaan BMT At Taqwa Halmahera di Kota Semarang. ${ }^{8}$

c. Kebutuhan Program

Program KJKS BMT merupakan program untuk mewujudkan akselerasi penanggulangan kemiskinan di Kota Padang. Program KJKS BMT merupakan lembaga Keuangan Mikro Simpan Pinjam dengan badan hukum Koperasi yang pengelolaannya dilaksanakan dengan menggunakan sistem syariah atau pola bagi hasil.

Berdasarkan tujuan penggunaan dana dapat dibedakan menjadi; (1) Pembiayaan modal kerja yaitu pembiayaan yang ditujukan untuk memberikan modal usaha seperti pembeliaan bahan baku atau barang modal (persediaan) yang akan diperdagangkan. (2) Pembiayaan investasi yaitu pembiayaan ditujan untuk modal usaha pembeliaan sarana/peralatan produksi dan atau pembeliaan barang modal berupa aktiva tetap/inventaris. (3) Pembiayaan konsumtif yaitu pembiayaan yang ditujukan untuk pembeliaan barang-barang konsumsi dan kebutuhan lainnya.

Pengenalan tentang program yang dilakukan pihak KJKS biasanya melakukan sosialisasi kepada masyarakat, dengan cara mengumpulkan masyarakat yang sebelumnya telah mendapat izin dari pihak Rt/Rw yang bersangkutan ini dinamakan Latihan Wajib Kelompok (LWK). Sosialisasi ini bertujuan untuk pengenalan program kepada masyarakat dan mengajak masyarakat untuk bergabung membentuk anggota dan kelompok dalam rangka bersama-sama membangun masyarakat yang aktif dalam kegiatan perekonomian yaitu dengan mendorong masyarakat untuk mau berusaha dan mengembangkan usaha dengan baik sesuai prinsip syariah melalui KJKS untuk itu dibutuhkan

\footnotetext{
${ }^{7}$ Variyetmi Wira, 'Upaya Penguatan Koperasi Jasa Keuangan Syariah Dalam Rangka Pemberdayaan Perekonomian Masyarakat Di Kota Padang', 2015, 47-54.

${ }^{8}$ Fitra Ananda and Achma Hendra Setiawan, 'Analisis Perkembangan Usaha Mikro Dan Kecil Setelah Memperoleh Pembiayaan Mudharabah Dari BMT At Taqwa Halmahera Di Kota Semarang', 2011.
} 
kerjasama yang baik antara KJKS dan Masyarakat agar menaati aturan yang berlaku di KJKS dengan rajin membayarkan simpanan wajib dan simpanan sukarela yang selama ini masih dilalaikan oleh masyarakat dalam pembayarannya. Menurut pengamatan peneliti masyarakat yang akan menjadi calon anggota KJKS kurang memiliki minat untuk mengikuti LWK yang di berikan oleh pihak KJKS karena mereka masih berfikir bahwa LWK tidak penting yang menjadi tujuan utama mereka hanya melakukan pembiayaan di KJKS.

Pengelolaan Koperasi Jasa Keuangan Syariah Baitul Maal Wat Tamwil (KJKS BMT) dalam Memberdayakan pelaku UMKM di Kota Padang harus terlaksana dengan maksimal menyentuh seluruh lapisan masyarakat. Sebagai wadah koordinasi dan integrasi penanggulangan kemiskinan di kelurahan tepat sasaran, kelembagaan KJKS BMT harus dikelola dengan profesional serta dituntut kreatif dalam menciptakan berbagai produk sehingga menurut pengamatan peneliti dilapangan masyarakat yang datang ke KJKS hanya memiliki keinginan untuk melakukan peminjaman saja bukan untuk melakukan penyimpanan atau menabungkan uang mereka di KJKS serta kreatif dalam pengembangkan usaha-usaha koperasi lainnya.

Program KJKS BMT merupakan program untuk mewujudkan akselerasi penanggulangan kemiskinan di Kota Padang. Program KJKS BMT merupakan lembaga Keuangan Mikro Simpan Pinjam dengan badan hukum Koperasi yang pengelolaannya dilaksanakan dengan menggunakan sistem syariah atau pola bagi hasil.

Sosialisasi dalam rangka pengenalan program, biasanya pihak KJKS terlebih dahulu melakukan sosialisasi kepada masyarakat, dengan cara mengumpulkan masyarakat yang sebelumnya telah mendapat izin dari pihak $\mathrm{Rt} / \mathrm{Rw}$ yang bersangkutan. Sosialisasi ini bertujuan untuk pengenalan program kepada masyarakat dan mengajak masyarakat untuk bergabung membentuk anggota dan kelompok dalam rangka bersama-sama membangun masyarakat yang aktif dalam kegiatan perekonomian yaitu dengan mendorong masyarakat untuk mau berusaha dan mengembangkan usaha dengan baik sesuai prinsip syariah melalui KJKS.

d. Dampak Program

Setiap program yang dilaksanakan oleh pemerintah tentu mempunyai tujuan dan tidak terkecuali untuk program KJKS BMT yang bertujuan untuk penanggulangan kemiskinan dengan memberikan bantuan berupa dana bergulir dalam menambah permodalan bagi UMKM. Program KJKS BMT ini mempunyai dampak dengan produk Pembiayaan yang dilakukan dalam penambahan modal Usaha membuat UMKM lebih termotivasi dalam pengembangan usahanya.

Program KJKS memberikan manfaat bagi pelaku usaha yang menjadi anggota KJKS untuk mengembangkan usaha yang dijalankan sehingga menambah penghasilan dan meningkatkan kesejahteraan diri dan keluarganya ditambah dengan sistim syariah yang digunakan dalam proses peminjaman yang tidak membutuhkan jaminan cukup dengan rasa kepercayaan terhadap anggota KJKS hal ini tentu dapat membantu sekali bagi masyarakat miskin yang mempunyai usaha namun kekurangan modal usaha sedangkan untuk jaminan sendiri mereka tidak memilikinya. 
Ada perbedaan dalam hal modal usaha, omzet penjualan dan keuntungan UMK sebelum dan sesudah memperoleh pembiayaan dari BMT At Taqwa Halmahera di Kota Semarang khususnya yang menjadi anggotanya. Dari variabel modal usaha, omzet penjualan dan keuntungan dalam UMK sesudah memperoleh pembiayaan dari BMT At Taqwa Halmahera terbukti mempunyai pengaruh positif terhadap kinerja UMK binaan BMT At Taqwa Halmahera di Kota Semarang. ${ }^{9}$

\section{Kendala-kendala Peran Program Koperasi Jasa Keuangan Syariah Baitul Maal Wat Tamwil (KJKS BMT) dalam Pemberdayaan UMKM di Kota Padang}

Pemberdayaan masyarakat di berbagai bidang tidak terlepas dari berbagai hambatan yang menyertainya. Hambatan yang sering muncul adalah sulitnya untuk mensinergiskan berbagai pemberdayaan itu dalam suatu program yang terpadu. Kendala yang terjadi dalam pelaksanaan program pemberdayaan dapat berasal dari kepribadian individu dalam komunitas dan bisa juga berasal dari sistem sosial. ${ }^{10}$

Program penanggulangan kemiskinan melalui pengembangan KJKS BMT diharapkan mampu menjembatani masyarakat miskin, agar mampu berdaya secara social, ekonomi dan lingkungan. Keberdayaan masyarakat miskin tersebut, diharapkan secara simultan mampu mengangkat kondisi mereka lebih sejahtera dan mampu terlepas dari kemiskinan. Program yang diambil pemerintah sebagai solusi dari permasalahan kekurangan modal dari UMKM ini diharapkan berjalan secara efektif.

Keberadaan rentenir di tengah-tengah masyarakat merupakan kompetitor yang sangat ingin ditekan keberadaanya dengan program KJKS namun pada kenyataannya keberadaan rentenir sangat susah di diatasi hal ini juga dikarenakan kelemahankelemahan dari KJKS itu sendiri misalnya dengan kekurangan modal usaha yang di alami KJKS serta administrasi yang masih berbelit-belit yang membuat masyarakat lebih memilih meminjam modal usaha kepada rentenir untuk penambahan modal usaha mereka. Kompetitor dengan produk yang sama seperti rentenir susah untuk ditekan keberadaannya hal ini disebabkan kurangnya modal serta administrasi yang masih berbelit-belit dari KJKS sehingga masyarakat masih memilih meminjam kepada rentenir karna terlalu lama menunggu hal ini mengakibatkan rasa kurang percaya anggota maupun masyarakat yang akan melakukan pembiayaan di KJKS.

\section{PENUTUP}

\section{Kesimpulan}

Setelah penulis memaparkan pembahasan tentang pemberdayaan ekonomi masyarakat melalui Koperasi Jasa Keuangan Syariah Mandiri Baitul Maal Wat Tamwil (KJKS BMT) ditinjau menurut perspektif pemberdayaan ekonomi terhadap Usaha Mikro Kecil Menengah (UMKM), maka penulis menarikkesimpulan sebagai berikut:

1. Upaya Program KJKS BMT untuk pemberdayaan UMKM di Kota Padang harus terlaksana dengan maksimal menyentuh seluruh lapisan masyarakat dengan merancang dan mengelola seluruh potensi yang ada ditengah-tengah masyarakat.

\footnotetext{
${ }^{9}$ Ananda and Hendra Setiawan.

${ }^{10}$ Zubaedi.
} 
KJKS BMT merupakan upaya Pemerintah dalam mengentaskan kemiskinan dan pengangguran di Kota Padang untuk itu kelembagaan KJKS BMT harus dikelola dengan profesional serta dituntut kreatif dalam menciptakan berbagai program dan usaha-usaha koperasi, melalui lembaga simpan pinjam maka diharapkan masyarakat miskin bisa terbantu serta memiliki akses untuk penambahan modal usaha.

2. KJKS merupakan organisasi terstruktur tokoh masyarakat, setiap unsur yang ada di Kelurahan mempunyai tugas meningkatkan ekonomi diwilayah mereka dengan bantuan penambahan modal usaha pembiayaan yang dilakukan, semua unsur harus bersinergi, bekerja keras, jujur, iklas karena itu merupakan kunci keberhasilan KJKS BMT ini bisa berkembang. Namun selama ini masih ada terjadi perselisihan mengakibatkan koordinasi yang terbangun kurang bagus dan menghambat laju pertumbuhan dari KJKS bisa dilihat dari Cakupan warga miskin penerima dana KJKS masih sangat sedikit mengisyaratkan bahwa kinerja yang kurang efektif dari setiap unsur yang berada di KJKS. Terlaksananya Program KJKS BMT ini tentunya memerlukan keseriusan dan dukungan dari berbagai pihak baik dari pemerintah maupun masyarakat dalam semua tahapan proses penyelengaraan kegiatannya. Hal ini tidak terlepas dari pengawasan dan bimbingan dari berbagai pihak yakni pemerintah setempat mulai dari Camat, lurah dan pemuka masyarakat, Pengelola, satuan kerja, fasilitator serta masyarakat namun temuan dilapangan selama ini masih ada terjadi perselisihan mengakibatkan koordinasi yang terbangun kurang bagus dan menghambat laju pertumbuhan dari KJKS. Konteks Program KJKS merupakan program percepatan penurunan kemiskinan, dari tahun 2010 sampai 2014 telah dibentuk 104 KJKS BMT di kota Padang terlaksananya program dengan baik perlu adanya pembagian tugas serta sosialisasi yang baik juga. Salah satu faktor pendukung tujuan program KJKS adalah pelaksanaan program KJKS dengan baik, masih adanya masyarakat yang menganggap program ini adalah uang pemerintah maka tidak masalah kalau pembiayaan yang diberikan tidak dikembalikan lagi, hal ini akan menghambat perkembangan usaha dari Program KJKS untuk itu di perlukan sosialisasi yang lebih baik lagi tentang program ini. Program KJKS BMT merupakan program untuk mewujudkan akselerasi penanggulangan kemiskinan di Kota Padang. Program KJKS BMT merupakan lembaga Keuangan Mikro Simpan Pinjam dengan badan hukum Koperasi yang pengelolaannya dilaksanakan dengan menggunakan sistem syariah atau pola bagi hasil.

3. Dalam penjelasan sebelumnya telah dijelaskan beberapa kendala yang sering dihadapi KJKS BMT dalam melakukan pemberdayaan UMKM diantaranya adalah kendala-kendala internal dan eksternal:

4. Faktor ekternal yaitu kondisi ekonomi makro yang tidak menentukan (krisis global) yang berimbas kepada turunnya pendapatan anggota/ nasabah, sehingga anggota/ nasabah mengalami kemacetan dalam pengembalian pinjaman, semakin banyaknya kompetitor dengan produk dan pelayanan yang kompetitif,.

5. Faktor internal yaitu modal yang terbatas pada KJKS, masih sulitnya merubah pola fikir masyarakat yang masih beranggapan bahwa dana yang disalurkan ini adalah uang bantuan cuma-cuma dari pemerintah dan tidak perlu dikembalikan, padahal dana yang digunakan ini harus dipertanggung jawabkan dan harus 
digulirkan kepada anggota lain yang membutuhkan tambahan modal usaha, kurangnya kesadaran dari anggota untuk melakukan kewajiban yaitu membayar simwa (Simpanan Wajib) di KJKS BMT sehingga pengurus dan pengelola harus datang menjemput ke rumah anggota. Masih kurangnya niat masyarakat untuk menabung di KJKS. Masih adanya beberapa KJKS yang belum berbadan Hukum padahal Program ini sudah berjalan mulai dari tahun 2010. Masih banyaknya KJKS yang masih tidak melaksanakan Rapat Akhir Tahun (RAT) tepat pada waktunya mengisaratkan bahwasanya KJKS itu tidak sehat dalam sistim pelaporan.

\section{Saran}

Dari hasil analisa dan penarikan kesimpulan diatas, penulis akan mengemukakan beberapa saran sebagai berikut:

1. Pemberdayaan ekonomi masyarakat melalui KJKS Mandiri Sejahtera yang dinilai berdampak baik hendaknya terus dikembangkan sehingga lebih banyak masyarakat yang terbantu yang merasakan manfaat dari program KJKS Mandiri Sejahtera.

2. Untuk mendorong kehidupan ekonomi syariah dalam kegiatan usaha mikro, kecil dan menengah khususnya dan ekonomi indonesia pada umumnya, prinsip-prinsip ekonomi syariah harus diterapkan sebaik mungkin agar masyarakat benar-benar memahami pentingnya mengembangkan ekonomi Islam. Hal ini meskinya dimulai dengan adanya pembinaan dan sosialisasi yang baik tentang pelaksanaan prinsip-prinsip Koperasi Jasa Keuangan syariah dalam kegiatan ekonomi.

Diharapkan bagi pengurus, Pengawas, pengelola, sekretariat KJKS serta Pemerintah dalam hal ini Dinas Koperasi dan UMKM Kota Padang untuk menjalankan fungsi dan tugas dalam mengawasi pelaksanaan dan penerapan prinsip-prinsip syariah.

\section{DAFTAR PUSTAKA}

Afrianti, Aan, 'Stratetegi Koperasi Jasa Keuangan Syariah Dalam Menekan Tingkat Non Performing Financing ( NPF): Studi Kasus Pada KJK Syariah Arrahmah Cinere' (UIN Syarif Hidayatullah, 2010)

Ananda, Fitra, and Achma Hendra Setiawan, 'Analisis Perkembangan Usaha Mikro Dan

Kecil Setelah Memperoleh Pembiayaan Mudharabah Dari BMT At Taqwa Halmahera Di Kota Semarang', 2011

'Dosen STISIP Imam Bonjol Padang'

Mahmudi, M, 'Manajemen Kinerja Sektor Publik' (Yogyakarta: UPP-STIM YKPN, 2010)

Sriyana, Jaka, and Fitri Raya, 'Peran Bmt Dalam Mengatasi Kemiskinan Di Kabupaten Bantul', Inferensi, 7 (2013), 29 <https://doi.org/10.18326/infsl3.v7i1.29-50>

Sudarsono, Heri, Bank dan Lembaga Keuangan Syariah (Ekonisia, 2008)

Wira, Variyetmi, 'Upaya Penguatan Koperasi Jasa Keuangan Syariah Dalam Rangka Pemberdayaan Perekonomian Masyarakat Di Kota Padang', 2015, 47-54 
Zubaedi, Pengembangan Masyarakat Wancana Dan Praktik, Ed 1. (Jakarta: Kencana, 2013) 